\title{
Pengaruh Bauran Pemasaran terhadap Keputusan Mengunjungi Festival Cap Go Meh di Singkawang
}

\author{
Putri Rizkiyah $^{1}$, Adinoto Nursiana ${ }^{2}$, Rahmat Ingkadijaya ${ }^{3}$ \\ ${ }^{1}$ Sekolah Tinggi Pariwisata Trisakti, pu3_rizky@yahoo.com \\ ${ }^{2}$ Sekolah Tinggi Ilmu Ekonomi Wiyatamandala, adinoto_n@yahoo.com \\ ${ }^{3}$ Sekolah Tinggi Pariwisata Trisakti, rachmatingkadijaya@stptrisakti.ac.id
}

\begin{abstract}
ABSTRAK
Festival Budaya Cap Go Meh yang diselenggarakan di Kota Singkawang merupakan festival budaya tahunan yang diselenggarakan pada hari kelima belas setelah perayaan Tahun Baru Cina (Imlek). Pada tahun 2016 tingkat kunjungan wisatawan menurun dari tahun-tahun sebelumnya yang mengakibatkan tidak tercapainya target yang ditetapkan pemerintah. Penelitian ini bertujuan untuk (1) mengidentifikasi profil atau karakteristik wisatawan domestik maupun mancanegara yang mengunjungifestival budaya Cap Go Meh di kota Singkawang, dan (2) mengetahui sejauhmana pengaruh unsur-unsur bauran promosi terhadap keputusan wisatawan mengunjungi festival budaya tersebut. Metode yang digunakan adalah metode survei, dengan menyebarkan kuesioner kepada 200 responden. Data dianalisis dengan menggunakan regresi linier berganda. Hasil penelitian menunjukkan bahwa secara simultan, bauran pemasaran tidak berpengaruh signifikan terhadap keputusan wisatawan mengunjungi Festival Budaya Cap Go Meh di Kota Singkawang, namun secara parsial hanya terdapat satu variabel yang berpengaruh yaitu variabel proses.
\end{abstract}

Kata kunci: Bauran pemasaran, keputusan wisatawan, wisata budaya, festival cap go meh

\section{ABSTRACT}

The Cap Go Meh Cultural Festival held in Singkawang City is an annual cultural festival held on the fifteenth day after the Chinese New Year celebration (Imlek).By 2016 the level of tourist arrivals decreased from previous years which resulted in the government's failure to achieve targets.This study aims to (1) identify the profile or characteristics of domestic and foreign tourists who visit the cultural festival Cap Go Meh in Singkawang city, and (2) find out how far the influence of promotion mix elements to the decision of tourists visiting the festival culture. The method used is survey method, by distributing questionnaires to 200 respondents.Data were analyzed by using multiple linear regression.The results showed that simultaneously, the marketing mix has no significant effect on the decision of tourists visiting Cap Go Meh Cultural Festival in Singkawang City, but partially there is only one influential variable that is process variable.

Keywords: Marketing mix, tourist decision, cultural tourism, cap go meh festival

Naskah Masuk : 27 Oktober 2017

Naskah Direvisi: 11 November 2017

Naskah Diterima : 16 Januari 2018

ISSN: 2355-6587, e-ISSN: 2528-2220

http://ejournal.bsi.ac.id/ejurnal/index.php/jp 


\section{PENDAHULUAN}

Di Kota Singkawang yang terletak pada Provinsi Kalimantan Barat, potensi pengembangan sektor pariwisata mempunyai prospek yang cukup potensial karena mempunyai berbagai jenis obyek wisata meliputi wisata alam, wisata tirta, kekayaan sejarah keunikan seni budaya, kekhasan cenderamata dan salah satunya adalah festival budaya tahunan Cap Go Meh. Festival Budaya Cap Go Meh yang diselenggarakan di Kota Singkawang merupakan festival budaya tahunan yang diselenggarakan pada hari ke lima belas setelah perayaan Tahun Baru Cina (Imlek). Tercatat pada tahun 2011 sebanyak 3.907 wisatawan, tahun 2012 sebanyak 4.038 wisatawan, tahun 2013 sebanyak 4.116, tahun 2014 sebanyak 4.216 tahun 2015 sebanyak 4.267 dan pada tahun 2016 hanya sebanyak 3.898 wisatawan datang untuk menghadiri festival tahunan ini.

Tercatat sejak tahun 2011 hingga 2015, grafik kunjungan wisatawan meningkat dari tahun ke tahun namun menurun pada tahun 2016. Target kunjungan wisatawan yang dibuat oleh Dinas Kebudayaan Pariwisata Pemuda dan Olah Raga Kota Singkawang terhadap Festival Cap Go Meh ini naik sekitar 10\% setiap tahun. Pada tahun 2011 dan 2012 kunjungan wisatawan pada Festival Cap Go Meh mencapai target, namun mulai tahun 2013 hingga tahun 2015 kunjungan wisatawan pada festival tahunan ini jauh dibawah dari target yang ditetapkan oleh Pemerintah Daerah Kota Singkawang walaupun secara jumlah kunjungan mengalami kenaikan, dan pada tahun 2016 tingkat kunjungan wisatawan menurun dari tahun-tahun sebelumnya yang mengakibatkan target yang ditetapkan pemerintah semakin tinggi.

Hal inilah yang menarik perhatian peneliti untuk kemudian melakukan sebuah penelitian terkait dengan upaya yang telah Pemerintah Kota Singkawang lakukan, salah satunya merujuk pada konsep bauran pemasaran 7P (Product, Price, Place, Promotion, Physical Evidence, Process and People). Sebagai sebuah studi analisis pengaruh bauran pemasaran terhadap keputusan wisatawan mengunjungi
Festival Budaya Cap Go Meh di Kota Singkawang.

Berdasarkan permasalahan tersebut di atas, maka tujuan penelitian ini adalah (1) mengidentifikasi profil atau karakteristik wisatawan domestik maupun mancanegara yang mengunjungi festival budaya Cap Go Meh di kota Singkawang, dan (2) mengetahui sejauhmana pengaruh unsurunsur bauran promosi terhadap keputusan wisatawan mengunjungi festival budaya Cap Go Meh di Kota Singkawang.

\section{KAJIAN LITERATUR}

Menurut UU Nomor 10 Tahun 2009, wisata adalah kegiatan perjalanan yang dilakukan oleh seseorang atau sekelompok orang dengan mengunjungi tempat tertentu untuk tujuan rekreasi, pengembangan pribadi, atau mempelajari keunikan daya tarik wisata yang dikunjungi dalam jangka waktu sementara. Wisatawan adalah orang yang melakukan wisata.

Menurut Kaeppler (1987), festival merupakan sarana komunikasi yang penting untuk membangun, memberdayakan, dan pengakuan suatu identitas budaya. Karakteristik setiap festival adalah unik, oleh karena itu tak ada satu model standar yang dapat digunakan untuk mengelola semua jenis festival. Menurut Williams (1983), terdapat tiga pengertian budaya antara lain pertama, budaya dapat digunakan untuk mengacu pada suatu proses umum perkembangan intelektual dan spiritual dan estesis. Kedua, budaya berarti pandangan hidup tertentu dari masyarakat, periode atau kelompok dan ketiga, budaya juga bisa merujuk pada karya dan praktik-praktik intelektual terutama artisitik.

Secara umum manajemen pemasaran didefinisikan sebagai seni dan ilmu untuk memilih pasar sasaran, mendapatkan, mempertahankan dan menumbuhkan pelanggan melalui penciptaan, penyampaian dan pengkomunikasian nilai yang unggul kepada pelanggan (Kotler \& Keller 2012).

Strategi yang dimaksud adalah bauran pemasaran yaitu produk (product), harga (price), saluran distribusi/lokasi (place), promosi (promotion), bukti fisik (physical 
evidence), proses (process) dan orang (people) (Kotler \& Levy, 1969).

Karena festival juga merupakan salah satu bentuk event, maka penting juga melihat pengelolaan yang meliputi bauran pemasarannya, karena pengelola festival tentunya menginginkan festival ini terus berlangsung dan dikunjungi banyak wisatawan.

Berangkat dari pemikiran tersebut, sudah seharusnya diadakan penelitian terhadap pengaruh bauran pemasaran yang meliputi product, price, place, promotion, physical evidence, process dan people terhadap keputusan wisatawan mengunjungi sebuah festival budaya, khususnya festival budaya Cap Go Meh yang diselenggarakan di Kota Singkawang.

Tidak hanya mengetahui pengaruh antara bauran pemasaran dan keputusan wisatawan mengunjungi festival budaya Cap Go Meh di Kota Singkawang, namun juga akan diketahui faktor demografi dari wisatawan yang berkunjung.

Hipotesis yang diuji dalam penelitian ini adalah sebagai berikut:

H1 Terdapat hubungan yang signifikan antara produk wisata terhadap keputusan wisatawan untuk mengunjungi Festival Budaya Cap Go Meh di Kota Singkawang

H2 Terdapat hubungan yang signifikan antara harga/biaya terhadap keputusan wisatawan untuk mengunjungi Festival Budaya Cap Go Meh di Kota Singkawang

H3 Terdapat hubungan yang signifikan antara promosi terhadap keputusan wisatawan untuk mengunjungi Festival Budaya Cap Go Meh di Kota Singkawang

H4 Terdapat hubungan yang signifikan antara lokasi / daerah tujuan wisata terhadap keputusan keputusan wisatawan untuk mengunjungi Festival Budaya Cap Go Meh di Kota Singkawang.

H5 Terdapat hubungan yang signifikan antara sarana fisik terhadap keputusan wisatawan untuk mengunjungi Festival Budaya Cap Go Meh di Kota Singkawang.
H6 Terdapat hubungan yang signifikan antara proses terhadap keputusan wisatawan untuk mengunjungi Festival Budaya Cap Go Meh di Kota Singkawang.

H7 Terdapat hubungan yang signifikan antara sumber daya manusia/orang (masyarakat sekitar) terhadap keputusan keputusan wisatawan untuk mengunjungi Festival Budaya Cap Go Meh di Kota Singkawang

\section{METODE PENELITIAN}

Teknik pengumpulan data dilakukan dengan menggunakan kuesioner dan juga wawancara yang merupakan teknik pengumpulan data utama dalam penelitian ini. Observasi dilakukan selama masa persiapan dan saat festival budaya Cap Go Meh berlangsung dan studi kepustakaan yang dilakukan untuk mengumpulkan informasi-informasi yang mendukung penelitian dengan tujuan memperdalam teori dan konsep yang dapat membantu menganalisis masalah yang diteliti.

Tabel 1.

Variabel Penelitian dan Pengukurannya

\begin{tabular}{|c|c|c|}
\hline Variabel & Indikator & Pengukuran \\
\hline Product & $\begin{array}{ll}\text { - } & \text { Daya tarik } \\
& \text { wisata } \\
\text { - } & \text { Fasilitas } \\
& \text { pendukung }\end{array}$ & \\
\hline Price & $\begin{array}{ll}\text { - } & \text { Harga } \\
\text { penginapan } \\
\text { - } & \text { Harga } \\
\text { transportasi } \\
\text { - } \\
\text { Harga } \\
\text { makanan } \\
\text { - } \begin{array}{l}\text { Harga } \\
\text { souvenir/cind } \\
\text { eramata }\end{array} \\
\end{array}$ & \\
\hline Promotion & $\begin{array}{ll}\text { - } & \text { Periklanan } \\
\text { - } & \text { Promosi } \\
& \text { penjualan } \\
\end{array}$ & Skala Likert \\
\hline Place & $\begin{array}{ll}\text { - } & \text { Lokasi } \\
\text { - } & \text { Keamanan } \\
\text { - } & \text { Transportasi }\end{array}$ & \\
\hline $\begin{array}{l}\text { Physical } \\
\text { evidence }\end{array}$ & $\begin{array}{ll}\text { - } & \text { Lingkungan } \\
\text { fisik } \\
\text { - Warna, logo }\end{array}$ & \\
\hline Process & $\begin{array}{ll}\text { - Upaya } \\
\text { perusahaan } \\
\text { jasa } \\
\text { - Kebutuhan \& } \\
\text { keinginan } \\
\text { pelanggan }\end{array}$ & \\
\hline
\end{tabular}




\begin{tabular}{ll}
\hline People & $\begin{array}{l}\text { Contractors } \\
\text { people }\end{array}$ \\
\hline
\end{tabular}

Variabel dalam penelitian ini diukur penulis menggunakan skala likert yang alternative jawabannya bergerak diantara skala 1- 5 .

Uji reliabilitas diukur dengan menggunakan cronbach's alpha, dimana digunakan untuk mengetahui apakah instrumen-instrumen yang digunakan dalam penelitian ini layak dan berkaitan atau tidak, dengan alpha $>0.6$.

Metode analisis data yang digunakan dalam penelitian ini adalah analisis regresi linier berganda yaitu analisis hubungan secara linear antara dua atau lebih variabel independen $\left(\mathrm{X}_{1}, \mathrm{X}_{2}, \ldots . \mathrm{X}_{\mathrm{n}}\right)$ dengan variabel dependen (Y). Analisis ini untuk mengetahui arah hubungan antara variabel independen dengan variabel dependen apakah masing-masing variabel independen berhubungan positif atau negatif dan untuk memprediksi nilai dari variabel dependen apabila nilai variabel independen mengalami kenaikan atau penurunan. Data yang digunakan biasanya berskala interval atau rasio.

Persamaan regresi linear berganda sebagai berikut:

$Y^{\prime}=a+b_{1} X_{1}+b_{2} X_{2}+\ldots . .+b_{n} X_{n}$

Keterangan:

$\mathrm{Y}^{\prime}=$ Variabel dependen (nilai yang

diprediksikan)

$\mathrm{X}_{1}$ dan $\mathrm{X}_{2}=$ Variabel independen

$\mathrm{a}=$ Konstanta (nilai $\mathrm{Y}^{\prime}$ apabila $\mathrm{X}_{1}$,

$\mathrm{X}_{2} \ldots . . \mathrm{X}_{\mathrm{n}}=0$ )

$\mathrm{b}=$ Koefisien regresi (nilai peningkatan ataupun penurunan)

Sampel penelitian ini diambil dari populasi wisatawan yang berkunjung ke Kota Singkawang untuk menyaksikan festival budaya tahunan Cap Go Meh. Populasi pada penelitian ini tidak diketahui secara pasti berapa jumlahnya. Hair et al (2009) mengatakan bahwa besarnya sampel penelitian dengan menggunakan regresi minimal adalah lima kali jumlah variabel independen dan paling ideal adalah 15-20 kali jumlah variabel independen. Dalam penelitian ini jumlah responden sebesar 200 orang

\section{PEMBAHASAN}

\section{Karakteristik Responden}

Berikut hasil analisis terhadap profil responden yang dibedakan atas lima kategori yaitu daerah asal, jenis kelamin, usia, pekerjaan dan etnis. Dilihat dari daerah asal responden, yang paling banyak berasal dari Jawa (77\%). Ini berarti festival Cap Go Meh di Kota Singkawang ini sudah diketahui oleh banyak orang dari Jawa.

Tabel 2.

Karakteristik Responden

\begin{tabular}{|c|c|c|c|}
\hline \multicolumn{2}{|c|}{ Karakteristik Responden } & Frekuensi & $\%$ \\
\hline \multirow{4}{*}{$\begin{array}{l}\text { Daerah } \\
\text { Asal }\end{array}$} & Sumatera & 26 & 13,0 \\
\hline & Jawa & 154 & 77,0 \\
\hline & Sulawesi & 16 & 8,0 \\
\hline & Papua & 4 & 2,0 \\
\hline \multirow{2}{*}{$\begin{array}{l}\text { Jenis } \\
\text { Kelamin }\end{array}$} & Laki-laki & 104 & 52,0 \\
\hline & Perempuan & 96 & 48,0 \\
\hline \multirow[t]{3}{*}{ Usia } & 21-30 tahun & 4 & $2 ., 0$ \\
\hline & $31-40$ tahun & 56 & 28,0 \\
\hline & $>40$ tahun & 140 & 70,0 \\
\hline \multirow[t]{5}{*}{ Pekerjaan } & Pelajar/mahasiswa & 3 & 1,5 \\
\hline & Pegawai swasta & 68 & 34,0 \\
\hline & Wiraswasta & 83 & 41,5 \\
\hline & Pensiunan & 26 & 13,0 \\
\hline & Lainnya & 20 & 10,0 \\
\hline \multirow[t]{7}{*}{ Etnik } & Jawa & 63 & 31,5 \\
\hline & Melayu & 30 & 15,0 \\
\hline & Batak & 3 & 1,5 \\
\hline & Tionghoa & 70 & 35,0 \\
\hline & Bugis & 2 & 1,0 \\
\hline & Sunda & 6 & 3,0 \\
\hline & Lainnya & 26 & 13,0 \\
\hline
\end{tabular}

Sumber: Hasil Pengolahan Data, 2016

Bila dilihat dari jenis kelamin responden yang mengunjungi festival, prosentasenya berimbang, sedangkan dari usia yang paling banyak adalah responden yang berusia lebih dari 40 tahun. Festival ini kurang diminati oleh kalangan muda (usia 21-30 tahun). Hal ini merupakan ancaman di kemudian hari yang harus dicarikan jalan keluarnya. Generasi muda diharapkan bangga terhadap budaya daerahnya dan mau memeliharanya karena kebanggaan terhadap budaya daerah tidak selalu berkorelasi dengan keinginan memeliharanya (Pramanik, et al., 2017).

Dilihat dari pekerjaan, yang paling banyak adalah wiraswasta $(41,5 \%)$ dan dan kedua 
adalah pegawai swasta, sedangkan bila dilihat dari etnik responden yang paling banyak dari etnik Tionghoa $(35,0 \%)$ dan yang kedua adalah dari etnik Jawa $(31,0 \%)$. Fenomena ini menarik, ternyata festival budaya etnik Tionghoa juga diminati oleh etnik Jawa.

\section{Uji Validitas dan Reliabilitas}

Uji validitas dihitung menggunakan program SPSS 23.0 dengan membandingkan nilai $\mathrm{r}$ hitung (correlated item-total correlation) dengan nilai $\mathrm{r}$ table. Jumlah pernyataan yang terdiri dari 29 butir terbagi menjadi tujuh variabel $\mathrm{X}$ dan 1 variabel $\mathrm{Y}$, yaitu produk (X1) terdiri dari 6 soal, harga (X2) terdiri dari 4 soal, promosi (X3) terdiri dari 3 soal, lokasi (X4) terdiri dari 2 soal, bukti fisik (X5) terdiri dari 3 soal, proses (X6) terdiri dari 2 soal, orang (X7) terdiri dari 2 soal dan keputusan wisatawan $(\mathrm{Y})$ terdiri dari 7 soal. Hasil uji validitas berdasarkan hasil kuesioner yang telah diolah oleh responden menunjukkan semua butir pertanyaan dinyatakan valid.

Hasil pengujian reliabilitas menggunakan SPSS 23.0 yang diujicobakan kepada 200 responden dan hasilnya sebagai berikut:

Tabel 3.

Hasil Uji Reliabilitas

\begin{tabular}{cccc}
\hline \multicolumn{3}{c}{ Item Total Statistics } \\
\hline & $\mathrm{N}$ & Cronbach's Alpha \\
\hline $\mathrm{X} 1$ & 196 & 4 & .503 \\
\hline $\mathrm{X} 2$ & 199 & 1 & .841 \\
\hline $\mathrm{X} 3$ & 197 & 3 & .016 \\
\hline $\mathrm{X} 4$ & 199 & 1 & .603 \\
\hline $\mathrm{X} 5$ & 200 & 0 & .733 \\
\hline $\mathrm{X} 6$ & 200 & 0 & .730 \\
\hline $\mathrm{X} 7$ & 200 & 0 & .558 \\
\hline $\mathrm{Y}$ & 194 & 6 & .276 \\
\hline Total & 191 & 9 & .620 \\
\hline
\end{tabular}

\section{Analisis Regresi Berganda}

Ketujuh variabel bebas (independent) dalam penelitian ini (product, price, promotion, place, physical evidence, process, dan people) dimasukkan dalam perhitungan regresi. Hasil pengolahan data adalah sebagai berikut.
Tabel 4.

Model Summary ${ }^{\mathrm{b}}$

\begin{tabular}{|l|c|r|r|r|}
\hline Model & $\mathrm{R}$ & $\begin{array}{c}\mathrm{R} \\
\text { Square }\end{array}$ & $\begin{array}{c}\text { Adjusted R } \\
\text { Square }\end{array}$ & $\begin{array}{c}\text { Std. Error of } \\
\text { the Estimate }\end{array}$ \\
\hline 1 & $.245^{\mathrm{a}}$ & .060 & .024 & .381 \\
\hline
\end{tabular}

a. Predictors: (Constant), People (Orang), Promotion

(Promosi), Product (produk), Price (Harga), Place

(Lokasi), Physical Evidende (Bukti Fisik), Process

(Proses)

b. Dependent Variable: Customer Decision

Berdasarkan tabel 4 dapat dijelaskan bahwa pada angka R square adalah 0.060 . hal ini berarti $0.6 \%$ dari keputusan wisatawan mengunjungi Festival Budaya Cap Go Meh di Kota Singkawang bisa dijelaskan oleh bauran pemasaran 7P. Sedangkan sisanya $(100 \%-0.6 \%=99.4 \%)$ dijelaskan oleh sebab-sebab yang lain.

Tabel 5. ANOVA $^{\mathrm{a}}$

\begin{tabular}{|c|c|c|c|c|c|}
\hline \multicolumn{6}{|c|}{$\mathrm{ANOVA}^{\mathrm{a}}$} \\
\hline Model & $\begin{array}{l}\text { Sum of } \\
\text { Squares }\end{array}$ & df & $\begin{array}{l}\text { Mean } \\
\text { Square }\end{array}$ & $\mathrm{F}$ & Sig. \\
\hline Regression & 1.695 & 7 & .242 & 1.668 & $.119^{\mathrm{b}}$ \\
\hline Residual & 26.569 & 183 & .145 & & \\
\hline Total & 28.264 & 190 & & & \\
\hline
\end{tabular}

a. Dependent Variable: Customer Decision

b. Predictors: (Constant), People (Orang),

Promotion (Promosi), Product (produk), Price

(Harga), Place (Lokasi), Physical Evidende (Bukti

Fisik), Process (Proses)

Berdasarkan uji ANOVA atau $\mathrm{F}$ tes di atas, didapat $\mathrm{F}$ hitung adalah 1.668 dengan tingkat signifikansi 0.119 . Karena 0.119 jauh lebih besar dari 0.05 , maka model regresi tidak dapat digunakan untuk mengetahui keputusan wisatawan mengunjungi Festival Budaya Cap Go Meh atau dengan kata lain, secara simultan tidak ada pengaruh yang signifikan antara variabel bauran pemasaran terhadap keputusan wisatawan mengunjungi Festival Cap Go Meh di Kota Singkawang. Secara parsial pengaruh variabel-variabel tersebut adalah sebagai berikut.

Produk $(X 1)=\mathbf{~ 0 , 0 5 3}$

Besarnya koefisien variabel produk yang berarti setiap kenaikan satu unit maka akan menyebabkan penurunan sebesar $-0,053$. 
Dengan kata lain, variabel produk berpengaruh terhadap keputusan wisatawan sebesar - 5\%. Meningkatnya produk yang kemudian menghasilkan penurunan keputusan wisatawan untuk berkunjung dapat terjadi jika tidak ada inovasi. Namun hasil penelitian pada variabel produk menunjukkan nilai signifikansi sebesar 0,429 yang berarti tidak ada hubungan yang signifikan antara produk dan kunjungan wisatawan pada Festival Cap Go Meh.

Dengan demikian, H1 yang berbunyi: "Terdapat hubungan yang signifikan antara produk wisata terhadap keputusan wisatawan untuk mengunjungi Festival Budaya Cap Go Meh di Kota Singkawang" ditolak.

\section{Harga $(X 2)=0,062$}

Besarnya koefisien variabel harga yang berarti setiap peningkatan sebesar satu unit, menyebabkan kenaikan sebesar 0,062 . Dengan kata lain, variabel harga berpengaruh terhadap keputusan wisatawan sebesar $6 \%$. Hasil regresi dari variabel harga yang terdiri dari harga penginapan, harga transportasi, harga makanan dan harga cenderamata, menunjukkan tidak adanya pengaruh yang signifikan terhadap keputusan wisatawan mengunjungi Festival Cap Go Meh di Kota Singkawang dengan nilai signifikan sebesar 0,246. Hal ini dikarenakan festival budaya ini hanya berlangsung selama satu tahun sekali dan merupakan atraksi wisata minat khusus sehingga harga tidak memengaruhi keputusan wisatawan.

Dengan demikian $\mathrm{H} 2$ yang berbunyi: "Terdapat hubungan yang signifikan antara harga/biaya terhadap keputusan wisatawan untuk mengunjungi Festival Budaya Cap Go Meh di Kota Singkawang" ditolak.

\section{Promosi $(\mathrm{X3})=0,020$}

Besarnya koefisien variabel promosi yang berarti setiap peningkatan sebesar satu unit, maka menyebabkan kenaikan sebesar 0,020. Dengan kata lain, variabel promosi berpengaruh terhadap keputusan wisatawan sebesar 2\%. Kecilnya persentase promosi ini dikarenakan minimnya upaya promosi yang dilakukan oleh Pemkot Singkawang.
Hasil wawancara yang peneliti lakukan terhadap ketua panitia Festival Cap Go Meh, bahwa mereka tidak melakukan promosi dikarenakan mereka menganggap bahwa festival ini sudah dikenal oleh masyarakat dan selalu dikunjungi ramai wisatawan. Yang mana menurut data, ternyata wisatawan yang hadir tidak mengalami peningkatan sesuai dengan target yang telah ditetapkan oleh Pemkot Singkawang.

Hasil penelitian ini menyatakan nilai signifikan variabel harga sebesar 0,721 > 0,05 yang berarti tidak ada pengaruh yang signifikan antara promosi dengan keputusan wisatawan mengunjungi Festival Cap Go Meh karena memang tidak adanya promosi yang dilakukan.

Dengan demikian H3 yang berbunyi: "Terdapat hubungan yang signifikan antara promosi terhadap keputusan wisatawan untuk mengunjungi Festival Budaya Cap Go Meh di Kota Singkawang" ditolak.

\section{Lokasi $(\mathrm{X} 4)=0,069$}

Besarnya koefisien variabel lokasi yang berarti setiap peningkatan sebesar satu unit, maka menyebabkan kenaikan sebesar 0,069 . Dengan kata lain, variabel lokasi berpengaruh terhadap keputusan wisatawan sebesar 6\%. Selain menjadi lokasi penyelenggaraan Festival Cap Go Meh, lokasi Kota Singkawang juga mudah diakses dan aman, akan meningkatkan keputusan wisatawan untuk berkunjung. Namun dengan nilai signifikan sebesar 0,188 menunjukkan bahwa tidak adanya pengaruh yang signifikan terhadap keputusan wisatawan mengunjungi festival budaya ini.

Dengan demikian, H4 yang berbunyi: "Terdapat hubungan yang signifikan antara lokasi / daerah tujuan wisata terhadap keputusan keputusan wisatawan untuk mengunjungi Festival Budaya Cap Go Meh di Kota Singkawang" ditolak.

\section{Bukti Fisik (X5) = -0,111}

Besarnya koefisien variabel bukti fisik yang berarti setiap peningkatan sebesar satu unit, menyebabkan penurunan sebesar $-0,111$. Dengan kata lain, variabel bukti fisik berpengaruh terhadap keputusan wisatawan sebesar $-11 \%$. Upaya yang dilakukan Pemkot Singkawang dalam 
mempersiapkan perayaan Festival Cap Go Meh terkait dengan variabel bukti fisik antara lain menata dan mendekorasi kota Singkawang sedemikian rupa ternyata tidak membuat kunjungan wisatawan meningkat. Dikarenakan minat orang berkunjung ke Kota Singkawang bukan karena bukti fisik tersebut, tetapi karena minat akan budaya terutama etnis tionghoa. Namun, hasil penelitian pada variabel bukti fisik ini menunjukan nilai signifikansi sebesar 0,67 yang berarti tidak ada pengaruh yang signifikan antara variabel bukti fisik terhadap keputusan wisatawan mengunjungi festival budaya Cap Go Meh di Kota Singkawang.

Dengan demikian, H5 yang berbunyi: "Terdapat hubungan yang signifikan antara sarana fisik terhadap keputusan wisatawan untuk mengunjungi Festival Budaya Cap Go Meh di Kota Singkawang" ditolak.

\section{Proses $(\mathrm{X6})=0,174$}

Besarnya koefisien variabel proses yang berarti setiap peningkatan sebesar satu unit, maka menyebabkan kenaikan sebesar 0,174 . Dengan kata lain, variabel proses berpengaruh terhadap keputusan wisatawan sebesar $17 \%$. Variabel proses merupakan satu-satunya variabel yang memiliki nilai signifikan $<0,05$ yang berarti variabel proses pada bauran pemasaran berpengaruh terhadap keputusan wisatawan mengunjungi Festival Cap Go Meh di Kota Singkawang. Dengan demikian, H6 yang berbunyi: "Terdapat hubungan yang signifikan antara proses terhadap keputusan wisatawan untuk mengunjungi Festival Budaya Cap Go Meh di Kota Singkawang" diterima.

Proses yang dimaksud pada penelitian ini adalah dukungan dari Pemerintah Kota Singkawang terhadap terselenggaranya Festival Cap Go Meh di Kota Singkawang. Adapun dukungan yang dilakukan oleh Pemkot Singkawang yaitu memberikan bantuan dana hibah kepada panitia Festival Cap Go Meh sebesar satu milyar rupiah, yang mana uang tersebut juga digunakan untuk memberikan subsidi kepada setiap tatung yang mengikuti pawai sebesar satu juta rupiah. Pada tahun 2016, tercatat di Kementerian Agama Kota Singkawang sebanyak 574 tatung yang mendaftarkan diri, namun pada pelaksanaannya, hanya sekitar 300 tatung yang mengikuti pawai. Ini disebabkan karena berkurangnya subsidi yang diberikan panitia dibandingkan tahun lalu sebesar 1,5 juta dan tahun-tahun sebelumnya sebesar 3 juta rupiah.

Maka dari itu, dukungan pemerintah sangat berpengaruh terhadap keputusan wisatawan mengunjungi festival budaya ini, karena harapan dari para wisatawan yang mengunjungi Festival Cap Go Meh adalah melihat pertunjukan tatung.

Orang $(X 7)=0,057$

Besarnya koefisien variabel orang yang berarti setiap peningkatan sebesar satu unit, menyebabkan peningkatan sebesar 0,057. Dengan kata lain, variabel orang berpengaruh terhadap keputusan wisatawan sebesar 5\%. Masyarakat kota Singkawang yang didominasi etnis Tionghoa memiliki nilai tambah dalam Festival Cap Go Meh. Dukungan dan keramahan masyarakat membantu meningkatkan kunjungan wisatawan. Namun berdasarkan hasil penelitian, nilai signifikansi pada variabel orang sebesar 0.365 yang berarti tidak ada hubungan yang signifikan antara variabel orang dan keputusan wisatawan mengunjungi Festival Cap Go Meh di Kota Singkawang. Dengan demikian $\mathrm{H} 7$ yang berbunti: "Terdapat hubungan yang signifikan antara sumber daya manusia/orang (masyarakat sekitar) terhadap keputusan keputusan wisatawan untuk mengunjungi Festival Budaya Cap Go Meh di Kota Singkawang" ditolak.

Tabel 6.

Coefficients $^{\mathrm{a}}$

\begin{tabular}{|c|c|c|c|c|c|c|}
\hline & \multirow[t]{2}{*}{ Model } & \multicolumn{2}{|c|}{$\begin{array}{l}\text { Unstandard. } \\
\text { Coefficients }\end{array}$} & \multirow{2}{*}{$\begin{array}{c}\begin{array}{c}\text { Standard. } \\
\text { Coefficients }\end{array} \\
\text { Beta }\end{array}$} & \multirow{2}{*}{$\mathrm{t}$} & \multirow{2}{*}{ Sig. } \\
\hline & & B & $\begin{array}{l}\text { Std. } \\
\text { Error }\end{array}$ & & & \\
\hline \multirow[t]{8}{*}{1} & (Constant) & 3.036 & .341 & & 8.894 & .000 \\
\hline & Product & -.053 & .067 & -.063 & -.793 & .429 \\
\hline & Price & .062 & .053 & .090 & 1.164 & .246 \\
\hline & Promotion & .020 & .056 & .026 & .357 & .721 \\
\hline & Place & .069 & .052 & .108 & 1.322 & .188 \\
\hline & $\begin{array}{l}\text { Physical } \\
\text { Evidence }\end{array}$ & -.111 & .058 & -.183 & -1.916 & .067 \\
\hline & Process & .174 & .062 & .274 & 2.790 & .005 \\
\hline & People & .057 & .063 & .089 & .908 & .365 \\
\hline
\end{tabular}




\section{PENUTUP}

Berdasarkan hasil penelitian, maka dapat ditarik kesimpulan bahwa wisatawan yang mengunjungi Festival Budaya Cap Go Meh di Kota Singkawang sebagian besar berasal dari Jawa (77\%) dan sebagian besar dari mereka berusia di atas 40 tahun dan dari etnis Tionghoa.

Hasil uji hipotesis menunjukkan bahwa dari tujuh hipotesis, hanya satu yang diterima yaiti H6, sedangkan enam hipotesis lainnya yaitu H1, H2, H3, H4, H5, dan H7 ditolak. Dengan demikian, dari tujuh variabel bauran pemasaran (product, price, promotion, place, physical evidence, process, dan people) hanya satu variabel yang berpengaruh signifikan, yaitu variabel proses. Hal ini dikarenakan Pemerintah Kota Singkawang turut andil dalam kesuksesan festival tersebut, dan tercapainya harapan wisatawan untuk menyaksikan ikon festival yaitu pertunjukkan pawai ratusan tatung.

Setelah mengamati dan menganalisis Festival Cap Go Meh di Kota Singkawang, penelitian ini menyarankan bahwa dukungan pemerintah (sebagai variabel proses) masih diperlukan dalam menyukseskan festival ini, terutama dalam meningkatkan atau mempertahankan jumlah tatung sebagai ikon festival.

Pemerintah daerah perlu meningkatkan subsidi bagi para tatung sebagai ikon festival karena berdasarkan data, berkurangnya tatung disebabkan kurangnya subsidi dari pemerintah.

\section{REFERENSI}

Hair, J. F., et al. (2009). Multivariate Data Analysis: A Global Perspective. 7th ed. Upper Saddle River: Prentice Hall.

\section{Kaeppler, A.L. (1987). Pacific} Festivals and Ethnic Identity. Dalam Alessandro Falassi (Ed.). Time Out of Time: Essays on the Festival (hlm.162-170). New Mexico: University of New Mexico Press.
Kotler, P. \& Keller, K.L. (2012). Marketing Management. 14th Edition. New Jersey: Pearson Education. Inc.

Kotler, P. \& Levy, S.J. (1969). Broadening the Concept of Marketing. Journal of Marketing, 33 (January), 10-15.

Pramanik, P.D., Gantina, D., Habibie, F.H. (2017). Kebanggaan dan Perilaku Memelihara Potensi Pariwisata. Jurnal Pariwisata, 4(2), 113-122.

Undang-Undang No. 10 Tahun 2009 Tentang Kepariwisataan.

Williams, R. (1983). Keywords: a Vocabulary of Culture and Society. New York: Oxford University Press

\section{BIODATA PENULIS}

Putri Rizkiyah, adalah alumni Program Magister Pariwisata di Sekolah Tinggi Pariwisata Trisakti.

Adinoto Nursiana, saat ini adalah dosen di Sekolah Tinggi Ilmu Ekonomi Wiyatamandala.

Rahmat Ingkadijaya, saat ini adalah dosen di Sekolah Tinggi Pariwisata Trisakti pada bidang Pariwisata. 